\title{
Rheological behaviour of water based mud formulated with sodium hydroxide $(\mathrm{NaOH})$ plant extracts
}

The rheological behaviour of drilling mud formulated with sodium hydroxide extracts of Bitter-leaf (BL), Pawpaw (PL), Almond (AL) and Moringa (ML) leaves applied as surfactant (emulsifiers) was studied. The rheological properties (plastic viscosity $(P V)$, yield point (YP), and gel strength) of the mud were measured using standard procedures. The mud specific gravity for BLEM and PLEM was observed to give same value (1.08) as that of the C1 mud. $\mathrm{pH}$ of the formulated mud were all alkaline and in the order BLEM (8.6) > PLEM (8.3) > ALEM (8.3) > C1(8.3) > MLEM (8.2) > C2 (8.2). The highest $P V(19 c P)$ was recorded by PLEM at $30^{\circ} \mathrm{C}$, while the least value (6cP) was by $C 2$ at $60^{\circ} \mathrm{C}$ temperatures. Highest YP (70 1b/100ft $\left.{ }^{2}\right)$ was recorded by $C 2$ while the lowest YP value $\left(22 \mathrm{lb} / 100 \mathrm{ft}^{2}\right)$ by $\mathrm{Cl}$ both at $30^{\circ} \mathrm{C} . \mathrm{Gel}$ strength at 10 seconds showed reduction in value as the temperature increased for MLEM, ALEM, C2 and C1 formulated mud and recorded maximum of $45 \mathrm{lb} / 100 \mathrm{ft}^{2}$ at $30^{\circ} \mathrm{C}$ for $\mathrm{C} 2$ while the lowest gel strength was reported by $\mathrm{Cl}$ at $60^{\circ} \mathrm{C}$. The results obtained from the study showed that the various alkaline plant extracts used as emulsifying agent have no negative effect on the rheological properties of the formulated mud, rather it enhances the rheological properties even after aging of the mud at $65^{\circ} \mathrm{C}$. These results therefore, show the need to use the various plant extracts as alternative additive (emulsifying agent) in the formulation of water based drilling mud.

Keywords: $\mathrm{NaOH}$-plant extracts, rheological properties, surfactant, drilling mud, emulsifying agent.

\subsection{Introduction}

$\mathrm{T}$ The foremost and most expensive step in the oil and gas industry is drilling of the wellbore. Cost for drilling represents $25 \%$ of the total oil field exploitation cost and are concentrated mostly in exploration and development

Blind peer reviews carried out

Messrs. Onyeogulu Chibuike and Akaranta Onyewuchi, World Bank Africa Center of Excellence Center for Oil Field Chemicals Research, University of Port Harcourt, P.M.B. 2, and Ibezim-Ezeani Millicent Uzoamaka, Department of Pure and Industrial Chemistry, University of Port Harcourt, P.M.B. 5323, Choba, Nigeria, Corresponding author: millicent.ibezim-ezeani@uniport.edu.ng of well drilling (Mohammed, 2007). Drilling mud, represents about $15-18 \%$ of the total cost of petroleum well drilling, must generally align with three important factors which includes: they should be easy to use, not too expensive and environmentally friendly. The complex drilling mud plays different roles simultaneously this includes:

i. Cooling and lubricating the drilling bit and string to minimize their wear and tear.

ii. Sealing off permeable formations by forming an impermeable, relatively thin mud cake at the borehole wall of the permeable formations.

iii. Creating an over balanced drilling condition to control the formation pressure.

iv. Hold drill cuttings in suspension when circulation is stopped.

v. Creating a buoyancy force to partly support the weight of the drill string and casing string.

vi. Reduction of formation damage of various horizons penetrated.

vii. Transmission of hydraulic horsepower to the bit and allowing maximum penetration rates.

viii. Carrying down the whole information from the drilled well in form of signals to the surface for interpretation, and so forth.

However, the success of any rotary drilling operation lies on the performance of the drilling mud applied for the drilling operation; which is also dependent on the rheological properties of the mud used. These rheological properties include plastic viscosity (PV), yield point (YP), gel strength and so on.

As petroleum explorers make exploitations in unconventional terrains such as deep water offshore fields, ultra high temperature, high pressure fields, arctic regions, etc; the cost of drilling for oil and gas reserves become more costly. From a drilling mud perspective, the demands of intrinsic to deep-water drilling and completions are especially acute as operators must reconcile performance and economic objectives with unique technical and environmental obstacles (Friedheim, 1998). These drilling 
environments require mud that have high performance. Therefore, measuring mud performance requires the evaluation of all key drilling parameters and their associated cost (Hughes, 2006). Overtime, the oil well drilling industry has basically made use of two types of drilling mud, waterbased mud (WBM) and oil-based mud (OBM). On the one hand, due to the cost effective nature and ease of formulation, water-based mud is mostly used as drilling mud. On the other hand, the oil-based mud despite being more expensive when compared to water based mud, are used because of their good rheological properties exhibited at temperatures as high as $260^{\circ} \mathrm{C}$; as well present better stability behaviour, effectiveness against all types of corrosion and superior lubricating properties.

Drilling mud has gone through various technological evolutions, since its first use in the United States, from applying a simple mixture of clays and water, to complex mixtures of various oilfield chemical used in recent times. These chemicals improve mud rheological properties, as well as filtration capability and allowing the bit to penetrate heterogeneous geological formations under the best conditions. However, the design and formulation of drilling mud in Nigerian over the years has been faced with the challenges of either importing these chemicals to formulate the mud, or in some cases import already designed and formulated drilling mud (Olatunde et al., 2011).

Water based drilling mud has water as its continuous phase. It is the most widely used systems, and are considered less expensive than oil-based fluids or synthetic based fluid. WBM are used to drilling approximately $80 \%$ of all well (Khodja et. al., 2010). Although OBM are amongst the less used drilling mud today because of their costly nature, but they usually gives better results when applied. The following ingredients are used for the formulation of water based mud; fresh water, bentonite, soda ash, caustic soda, polyanionic cellulose (PAC L), xanthum gum biopolymer (XCD polymer), $\mathrm{KCl}$ salt, barite and surfactant (emulsifying agent). However, these additives are used in different proportions in designing a drilling mud so as to meet its purpose such as good density, mud rheology and fluid loss control property (Amanullah et al., 2016). In the process of searching for these mud properties, preservation of environment is a global concern and many organizations are advised to use nontoxic drilling mud additives. Pollution of the environment has been a serious threat, while drilling wells that are complex with high temperatures which are managed by use of high performance WBM and OBM (Talukdar et al., 2018).

This research tends to explore the use of sodium hydroxide plant extracts (pawpaw, moringa, bitter-leaf and almond leaves) as mud additives (emulsifiers) in the formulation of drilling muds, and hence observe their effects on the rheological properties of the formulated muds.

\subsection{Materials and methods}

\subsection{Plant Materials Collection}

The plant leaves samples were obtained from Choba area in Port Harcourt, Rivers states, Nigeria. Taxonomic identification of fresh green leaves was carried out at University of Port Harcourt in the Department of Plant Science and Biotechnology. The samples were preserved in a clean plastic bag which was then transported to the laboratory for the study. The leaves were shade-dried for six weeks before crushing into fine powder with an electric milling machine. The powdered plant samples were kept in air tight containers and labeled prior to use.

\subsection{Extraction Process}

The grounded plant material ( $25 \mathrm{~g}$ each) was soaked in $4 \mathrm{M}$ $\mathrm{NaOH}$ solution of $250 \mathrm{ml}$ each at $70^{\circ} \mathrm{C}$ for 40 minutes with occasional shaking. The next process was filtering with Whatman No.1 filter paper. The crude extracts were then transferred into airtight containers and reserved preceding to the drilling mud formulation.

\subsection{CHARACTERIZATION OF PLANT EXTRACTS}

\subsubsection{Foam test}

Robot Marie Model was used to determine foam characteristics of the $\mathrm{NaOH}$-plant extracts. Foaming properties of the extract were determined using $50 \mathrm{ml}$ of the crude extract. The extracts were placed in a $150 \mathrm{ml}$ measuring cylinder. The content in every measuring cylinder was covered with thumb at the top and the extract shaken 50 times and then allowed to settle in the cylinder for 1 minute. Measurement of the foam volume was taken at this initial time. Measurements were also recorded at the time of complete disappearance of the last trace of foam. The presence of saponins is indicated when a stable foam is formed (Eka et al., 2017). The experiment was conducted in triplicates.

\subsubsection{FTIR characterization}

All the crude extracts from the four plants were subjected to FTIR spectroscopy. FTIR results were recorded in the solidstate as $\mathrm{KBr}$ pellet was used; the dispersion was done using the FTIR spectrometer.

The crude extract was mixed with $\mathrm{KBr}$ (IR-grade) at a ratio of 1:100 and pressed to a pellet. The pellet was put into the sample holder of Perkin Elmer spectrophotometer and the scanning range was between $4000-500 \mathrm{~cm}^{-1}$. Functional groups present in the crude extracts of the plants were obtained through the spectral data.

\subsection{3 $\mathrm{pH}$}

The $\mathrm{pH}$ meter's electrode was lowered into a buffer solution, with the temperature then adjusted to $27^{\circ} \mathrm{C}$ using the temperature regulator. The instrument was then calibrated at a buffer of $\mathrm{pH}$ 7. The electrode was then removed from the buffer and rinsed with distilled water. Next, it was then dipped 
into the beaker containing the extract and the $\mathrm{pH}$ on the screen of $\mathrm{pH}$ meter was recorded.

\subsubsection{Conductivity}

The conductivity meter's electrode was lowered into a standard solution, with the temperature recorded at $26.7^{\circ} \mathrm{C}$ from the temperature regulator. The instrument was calibrated using the standard solution. The electrode was then removed from the solution and rinsed with distilled water. Next, it was then dipped into the beaker containing the extract and the conductivity on the screen of conductivity meter was recorded.

\subsubsection{Surface tension}

Surface tension of the extracts was determined using a Wilhelmy plate tensiometer. In this method a thin plate (often made of platinum) was used to measure equilibrium surface or interfacial tension at air-liquid or liquid-liquid interfaces. The plate is oriented perpendicularly to the interface and the force exerted on it is measured. The plate was cleaned thoroughly in a burner flame and was then attached to a scale by means of a thin metal wire. The plate was moved downwards by a control nob, towards the extract surface until the meniscus connects with it. The force acting on the plate due to the wetting by the extract was measured by a tensiometer and then recorded. However, the process was performed in triplicate.

\subsubsection{Density}

The weight of a $50 \mathrm{ml}$ density bottle was determined using an electronic weighing balance. $50 \mathrm{ml}$ of the plant extract was poured into it and the weight was noted. The formula was use in obtaining the density of the extract.

$$
\text { Density }=\frac{\text { Mass of extract }}{\text { Volume of extract weight }}
$$

\subsubsection{Viscosity}

Viscosity of the extracts was measured using the Ostwald viscometers, named after Wilhelm Ostwald. The calibration was done using a fluid of known properties. The fluid was drawn into the upper bulb by suction, and then allowed to flow down through the capillary into the lower bulb. Two marks (one above and one below the upper bulb) indicate a known volume. The time taken for the level of the liquid to pass between these marks and then multiply by the viscometer constant is proportional to the kinematic viscosity. The dynamic viscosity was then deduced by multiplying the kinematic viscosity by the density of the fluid. The plant extracts viscosity was also measured using same process and the temperature at which it was carried out were also recorded.

\subsection{Mud Preparation}

\subsubsection{Formulation of drilling mud}

The mud formulation encompassed the following ingredients: water (base fluid), bentonite (viscosifier), caustic soda ( $\mathrm{pH}$ control), soda ash (calcium precipitant), PAC L (fluid loss and viscosifier), XCD polymer (fluid loss and viscosifier), $\mathrm{KCl}$ salt (inhibitor), barite (weighting agent), commercial surfactant (emulsifiers/rheology modifier), NaOH-plant extracts (pawpaw, moringa, almond and bitter-leaf).

Bentonite clay was pre-hydrated for 16 hours $(340 \mathrm{ml}$ of water $+22.5 \mathrm{~g}$ of bentonite), for proper yielding and viscosifying of the bentonite. Each other additive was added into the per-hydrated bentonite at various time intervals with constant agitation using a beach mixer, following the order in Table 1 (Yunita et al., 2015).

Different formulations were done using the different $\mathrm{NaOH}$-plant extract, as well as the control mud (mud with commercial surfactant and mud without surfactant) and each mud formulation is indicated in Table 1. All the chemicals used were made available by Hamilton Technologies Limited.

\subsection{Experimental Procedures}

\subsubsection{Mud specific gravity and $\mathrm{pH}$}

Mud specific gravity was measured using a mud balance (Ihenacho et al., 2016), which was measured for all the mud formulated. $\mathrm{pH}$ meter was used to determine the alkalinity of the formulated mud due to the different plant extracts used in the mud formulation.

Table 1: Composition of CONTROL and NaOH PLANT EXTRACtS DRILling MUd

\begin{tabular}{lcccc}
\hline \multicolumn{1}{c}{ Mud components } & Control mud & Plant extractmud & Time interval (mins) & Function \\
\hline Pre-hydrated bentonite & $\begin{array}{c}340 \mathrm{ml} \text { of water }+ \\
22.5 \mathrm{~g} \text { bentonite }\end{array}$ & $\begin{array}{c}340 \mathrm{ml} \text { of water }+ \\
22.5 \mathrm{~g} \text { bentonite }\end{array}$ & & $\begin{array}{c}\text { Base fluid and } \\
\text { viscosifier }\end{array}$ \\
\hline Soda ash & $0.5 \mathrm{~g}$ & $0.5 \mathrm{~g}$ & 960 & Calcium precipitant in low pH mud \\
Caustic soda & $0.5 \mathrm{~g}$ & $0.5 \mathrm{~g}$ & 5 & Alkalinity stabilizers \\
PAC L & $1.25 \mathrm{~g}$ & $1.25 \mathrm{~g}$ & 5 & Fluid loss and viscosifier \\
XCD polymer & $3 \mathrm{~g}$ & $3 \mathrm{~g}$ & 5 & Fluid loss and viscosifier \\
KCl salt & $5 \mathrm{~g}$ & $5 \mathrm{~g}$ & 5 & Inhibitor \\
Barite & $56 \mathrm{~g}$ & $56 \mathrm{~g}$ & 5 & Weighting agent. \\
Commercial surfactant & $5 \mathrm{ml}$ & - & 5 & Emulsifiers/rheology modifier \\
Plant extracts & - & $5 \mathrm{ml}$ & 5 & Emulsifiers/rheology modifier \\
\hline
\end{tabular}




\subsubsection{Rheological properties}

The rheological properties of the formulated mud were measured according to the American Petroleum Institute (API) standard procedures (Tchameni et al., 2018). Plastic viscosity (PV), yield point (YP) and gel strength (at 10 seconds and 10 minutes) was measured using Fann viscometer (Mohideen et al., 2019). The rheological properties were measured at the test temperatures $\left(30,49\right.$ and $\left.60^{\circ} \mathrm{C}\right)$.

\subsubsection{Filtration loss}

API fluid loss apparatus Fann HPHT filter press was used at $121^{\circ} \mathrm{C}$ and $500 \mathrm{psi}$; and the filtrate obtained after 30 minutes ( $\Delta \mathrm{P}=500 \mathrm{psi}$, Whatman filter paper no 5). The volume of filtrate loss was recorded from the graduated cylinder at the end of 30 minutes (Agwu et al., 2015).

\subsubsection{Aging process}

The thermal stability test involve heating the drilling mud from room temperature to a testing temperature $\left(65^{\circ} \mathrm{C}\right)$ for 16 hours in a roller oven and then cooling it back to room temperature (Agwu et al., 2015), before testing the drilling mud properties (PV, YP and gel strength). Temperature of $49^{\circ} \mathrm{C}$ was taken as standard temperature to measure rheological properties of the mud (Tchameni et al., 2018) after aging, while temperature at $65^{\circ} \mathrm{C}$ was taken as the standard aging temperature for drilling mud.

\subsection{Results and discussion}

TABLE 2: ACRONYMS USED FOR THE STUDY

\begin{tabular}{lcc}
\hline Name & $\begin{array}{c}\text { Plant powder } \\
\text { labeling }\end{array}$ & $\begin{array}{c}\text { Mud } \\
\text { labeling }\end{array}$ \\
\hline Pawpaw leaves extract mud & PL & PLEM \\
Moringa leaves extract mud & ML & MLEM \\
Almond leaves extract mud & AL & ALEM \\
Bitter leaves extract mud & BL & BLEM \\
Mud with commercial emulsifier & & C1 \\
Mud without emulsifier & & C2 \\
\hline
\end{tabular}

\subsection{Foaming Properties of NaOH Plant Extract}

Drainage affects the lifetime of foam because when the bubbles are closer to each other, films of liquid break ultimately leading to the collapse of foam (Rio et al., 2014). From Table 3, it was observed that BL extract gave the highest foam volume $(15.96 \mathrm{ml})$, while ML extract gave the lowest foam volume (3.99

TABle 3: FoAm VOLUME AND TIME TAKEN FOR FOAM TO DISAPPEAR FOR THE VARIOUS PLANT EXTRACT

\begin{tabular}{ccc}
\hline $\mathrm{NaOH}$ Extracts & Foamvolume $(\mathrm{mL})$ & $\begin{array}{c}\text { Time taken for the } \\
\text { foam to dissappear } \\
\text { (seconds) }\end{array}$ \\
\hline $\mathrm{BL}$ & 15.96 & 600 \\
$\mathrm{PL}$ & 5.32 & 4400 \\
$\mathrm{ML}$ & 3.99 & 300 \\
$\mathrm{AL}$ & 6.65 & 30 \\
\hline
\end{tabular}

$\mathrm{ml})$. Also, PL extract gave the longest time (4400 seconds) for foam disappearance. This long time taken by the foam reflects the strength of the foam which directly implies that PL extract have large number of foaming components (saponins) which is in agreement with the studies done on aqueous extract of PL (Huo et al., 2016). Also, saponins with single sugar chains have the best foaming characteristic, thus the higher the sugar chain, the lesser the foaming (Jain et al., 2019). AL extract recorded the least of foam disappearance time (30 seconds) and this could be because its foaming properties are weak and collapse fast. The test on the crude $\mathrm{NaOH}$-plant extracts showed that all the extracts contain saponins.

TABLE 4: FTIR ABSORPTION BANDS AND THEIR POSSIBLE GROUP ASSIGNMENTS WITH NAOH-PLANT EXTRACTS

\begin{tabular}{lcccc}
\hline $\begin{array}{l}\text { Possible functional } \\
\text { groups }\end{array}$ & \multicolumn{4}{c}{ Absorption bands $\left(\mathrm{cm}^{-1}\right)$} \\
\cline { 2 - 5 } & $\mathrm{BL}$ & $\mathrm{PL}$ & $\mathrm{AL}$ & $\mathrm{ML}$ \\
\hline O-H stretching & 3356.25 & 3742.03 & 3387.11 & 3834.61 \\
& & 3379.40 & & \\
N-H stretching & & & & 3371.68 \\
& & & & 3286.81 \\
C-H stretching & 2090.91 & 2330.09 & 2106.34 & \\
& & 2098.40 & & \\
C=O stretching & & & & 1928.88 \\
C=C stretching & 1643.41 & 1643.41 & 1634.41 & 1643.14 \\
O-C=O stretching & 1404.22 & 1411.94 & 1411.94 & 1411.94 \\
\hline
\end{tabular}

\subsection{FTIR INTERPRETATION FOR NAOH-PLANT EXTRACTS}

The absorption peak 1411.94 and $1643.41 \mathrm{~cm}^{-1}$, occurs in all the $\mathrm{NaOH}$ extracts and it shows the presence of $\mathrm{C}-\mathrm{O}$ of carboxylic ester and $\mathrm{C}=\mathrm{C}$ due to aromatic ring respectively.

Absorption peak greater than $3200 \mathrm{~cm}^{-1}$ occurs also in the plant extracts and all the peaks where observed to be broad peaks indicating the presence of $\mathrm{O}-\mathrm{H}$ phenolic groups (Fadare et al., 2015). However, the ML extract showed more of the phenolic peaks than the others.

The absorption peaks $2090.91 \mathrm{~cm}^{-1}$ (BL), $2106.34 \mathrm{~cm}^{-1}$ (AL), and $1925.55 \mathrm{~cm}^{-1}$ (ML), indicate the presence $\mathrm{C}-\mathrm{H}$ stretch of the aromatic compounds (Fasya et al., 2019).

Table 5: Physicochemical PROPERTIES of NaOH-PLANT EXTRACtS

\begin{tabular}{lcccc}
\hline $\begin{array}{l}\text { Physicochemical } \\
\text { properties }\end{array}$ & \multicolumn{4}{c}{$\mathrm{NaOH}$ Plant extracts } \\
\cline { 2 - 5 } & $\mathrm{BL}$ & $\mathrm{PL}$ & $\mathrm{AL}$ & $\mathrm{ML}$ \\
\hline $\mathrm{pH}$ at $27^{\circ} \mathrm{C}$ & 15.86 & 15.72 & 15.72 & 15.86 \\
$\begin{array}{l}\text { Conductivity } \\
(\mathrm{ms} / \mathrm{cm}) \text { at } 26.7^{\circ} \mathrm{C}\end{array}$ & 127.40 & 118.30 & 124.00 & 124.50 \\
$\begin{array}{l}\text { Surface tension } \\
(\mathrm{mN} / \mathrm{m}) \text { at } 32.5^{\circ} \mathrm{C}\end{array}$ & 39.60 & 35.90 & 41.80 & 39.00 \\
$\begin{array}{l}\text { Density }\left(\mathrm{g} / \mathrm{cm}^{3}\right) \\
\text { at } 32.5^{\circ} \mathrm{C}\end{array}$ & 1.13 & 1.13 & 1.14 & 1.16 \\
$\begin{array}{l}\mathrm{Kinematic} \text { viscosity } \\
(\mathrm{cSt}) \text { at } 32.5^{\circ} \mathrm{C}\end{array}$ & 2.22 & 2.26 & 2.55 & 3.02 \\
$\begin{array}{l}\text { Dynamic viscosity } \\
(\mathrm{cP}) \text { at } 32.5^{\circ} \mathrm{C}\end{array}$ & 2.52 & 2.54 & 2.91 & 3.51 \\
\hline
\end{tabular}



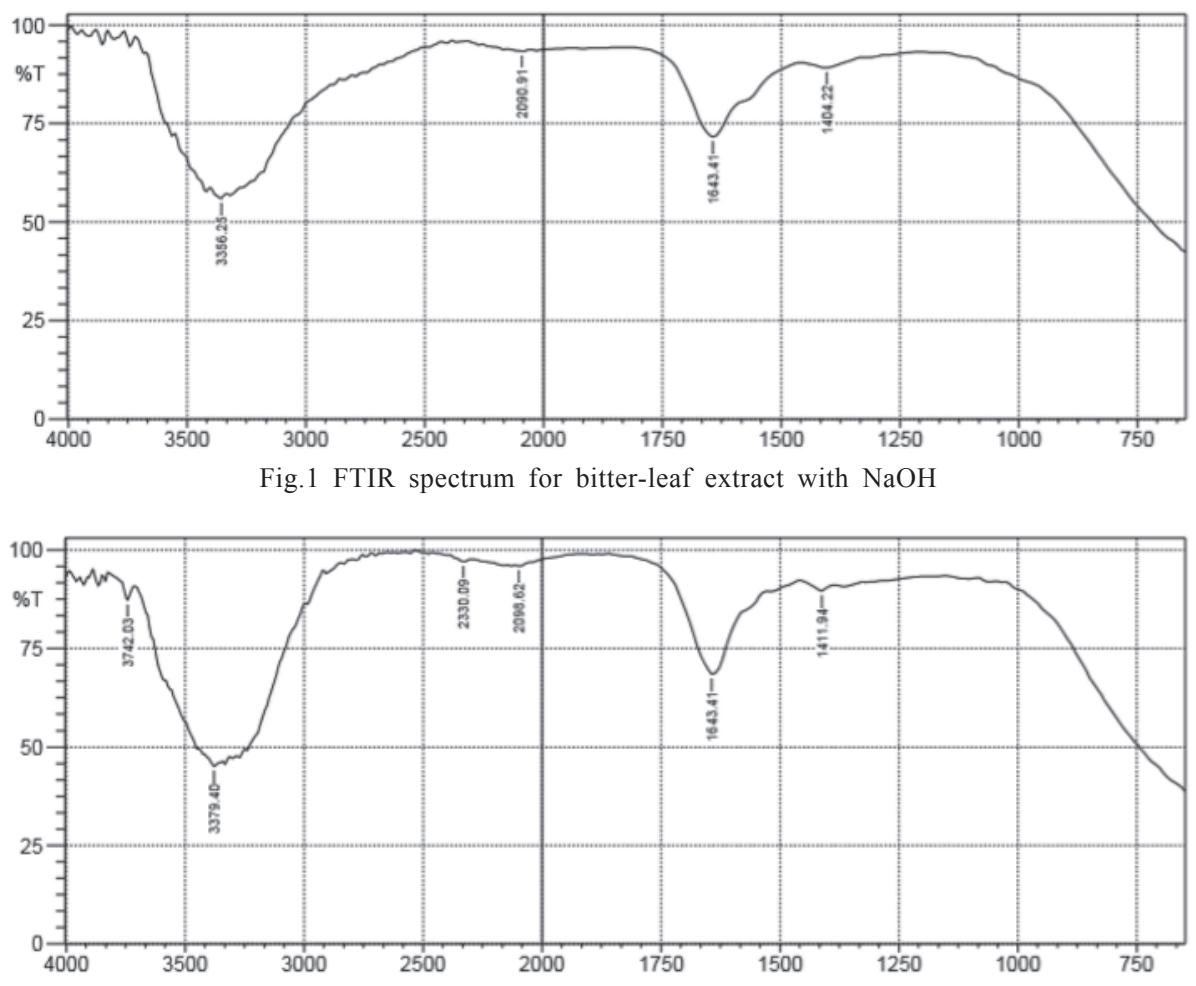

Fig.2 FTIR spectrum for pawpaw leaf extract with $\mathrm{NaOH}$

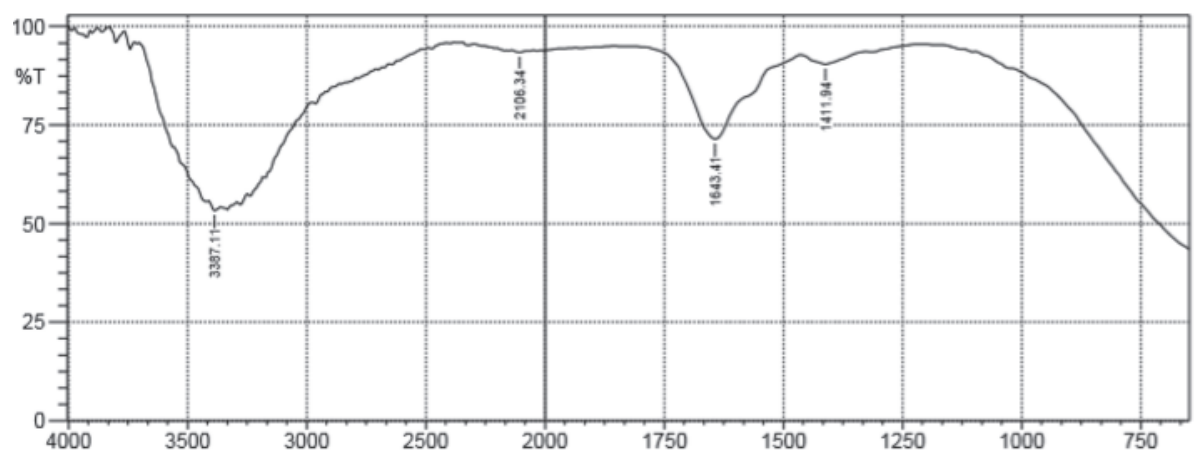

Fig.3 FTIR spectrum for almond leaf extract with $\mathrm{NaOH}$

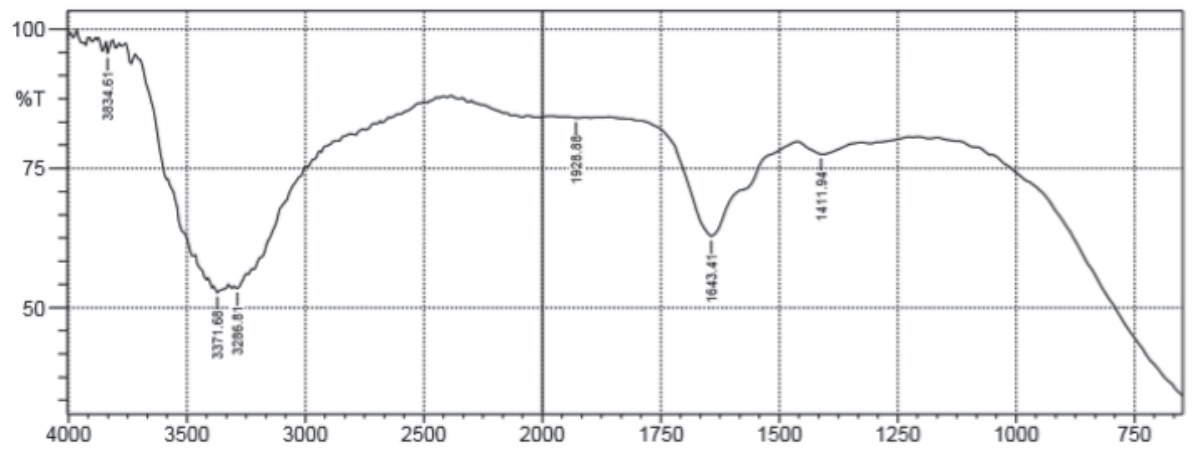

Fig.4 FTIR spectrum for moringa leaf extract with $\mathrm{NaOH}$

value 1.08 for BLEM, PLEM and C1; while ALEM, MLEM and C2 mud gave 1.07. Value of 1.07 for $\mathrm{C} 2$ could be attributed to the absent of any emulsifying material in the C2 mud, while that of ALEM and MLEM could be as a result of not having enough weighting components in the plant extracts, thus resulting to reduction in the specific gravity. The $\mathrm{pH}$ of the various mud samples was alkaline, with BLEM being more alkaline compare to other plant extract formulated muds. The alkalinity of the muds are in the order; BLEM (8.6) > PLEM (8.3) > $\operatorname{ALEM}(8.3)>\mathrm{C} 1(8.3)>\operatorname{MLEM}(8.2)>$ C2 (8.2). The alkalinity of these muds can be attributed to the active components (sponins, flavonoids, etc.) of the various plants extract. However, alkalinity of drilling mud is a necessary parameter because its helps to neutralize the acidic gases produced during drilling which might lead to corrosion of the metal parts of the drilling equipment (Akintola et al., 2014).

\subsection{Rheological Properties}

Three different temperatures (30, 49 and $60^{\circ} \mathrm{C}$ ), were used to check their effect on the rheological properties of the mud. The Bingham model was used to explain the behaviour of the drilling muds which determines the plastic viscosity and yield point from equations 1 and 2 .

$\mathrm{PV}(\mathrm{cP})=600 \mathrm{rpm}-300 \mathrm{rpm}$

YP $\left(\mathrm{lb} / 100 \mathrm{ft}^{2}\right)=(\mathrm{PV})-(300 \mathrm{rpm}) .$.

The dial reading results of the various formulated drilling mud at various test temperatures are presented in Tables 6 and 7.

\subsubsection{Plastic viscosity}

Increase in temperature resulted to a decrease in the PV values of the various muds with the exception of MLEM which was constant as the temperature increases (Fig.7). High

3.3 Mud SPECIFIC GRAVITY AND PH

The results of the mud specific gravity and $\mathrm{pH}$ of the formulated mud are shown in Figs.5 and 6. The specific gravity of the various formulated muds was observed to give temperature degrades some of the mud additives as reported by Jimoh et al., (2018). PV of control mud (C2), recorded lower values of PV $\left(9,8\right.$ and $6 \mathrm{cP}$ at 30,49 and $60^{\circ} \mathrm{C}$ respectively) compared to the drilling muds with $\mathrm{NaOH}-$ plant extracts. 


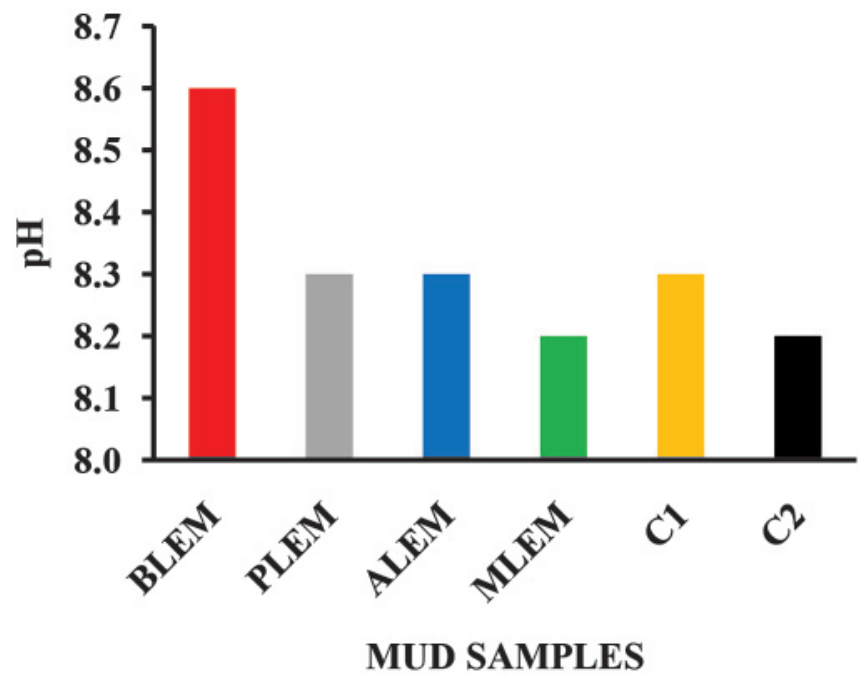

Fig.5 $\mathrm{pH}$ of formulated drilling mud

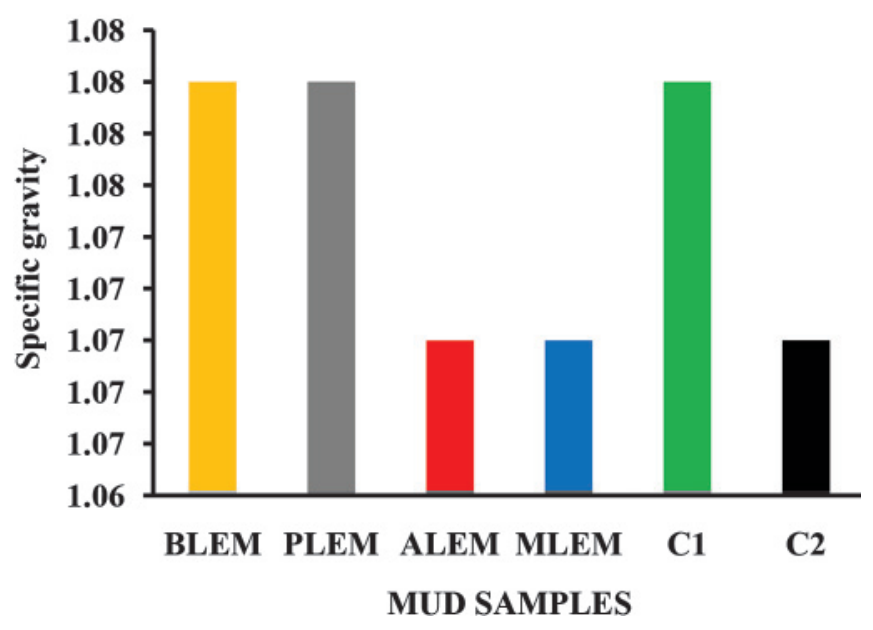

Fig.6 Specific gravity of formulated drilling muds

Comparing the plant extract mud, PLEM recorded the highest value of $\mathrm{PV}(19 \mathrm{cP})$ at $30^{\circ} \mathrm{C}$, while ALEM recorded the lowest value $(9 \mathrm{cP})$ at $60^{\circ} \mathrm{C}$. Decrease in PV is observed as a result of an increase in flocculation in the mud system, thus leading to a decrease in the internal friction of the mud as the solid volume in the mud reduces, and allowing free movement of the mud aggregates in the aqueous phase (Dong et al., 2015).

\subsubsection{Yield point}

The results show that there is an increase in YP as the
TABLE 7: DiAL READING RESULTS OF THE CONTROL MUD

\begin{tabular}{|c|c|c|c|c|c|c|}
\hline \multicolumn{7}{|c|}{ Mud type/temperature } \\
\hline \multirow[t]{2}{*}{ RPM } & \multicolumn{3}{|c|}{$\begin{array}{l}\text { Mud with commercial } \\
\text { surfactant (emulsifier) (C1) }\end{array}$} & \multicolumn{3}{|c|}{$\begin{array}{l}\text { Mud without surfactant } \\
\text { (emulsifier) }(\mathrm{C} 2)\end{array}$} \\
\hline & $30^{\circ} \mathrm{C}$ & $49^{\circ} \mathrm{C}$ & $60^{\circ} \mathrm{C}$ & $30^{\circ} \mathrm{C}$ & $49^{\circ} \mathrm{C}$ & $60^{\circ} \mathrm{C}$ \\
\hline 600 & 54 & 51 & 49 & 88 & 80 & 72 \\
\hline 300 & 38 & 37 & 36 & 79 & 72 & 66 \\
\hline 200 & 31 & 35 & 29 & 69 & 68 & 62 \\
\hline 100 & 23 & 32 & 21 & 65 & 60 & 55 \\
\hline 6 & 9 & 10 & 9 & 30 & 23 & 20 \\
\hline 3 & 8 & 9 & 8 & 22 & 20 & 19 \\
\hline
\end{tabular}

temperature increased for BLEM, PLEM, ALEM and C1, while a decrease in YP as temperature increases in the case of MLEM and C2. A decrease in YP with temperature increase in the study to improve rheology of WBM with moringa leaves was observed by Biwott et al., (2019). Increase in YP might be as a result of the surface active components (saponins) present in the plant materials which acts as surfactants in the mud; thus forming long molecule chain within the mud and causing an increase in the mud YP (Avic and Mert, 2019). C2 mud gave the highest value of $\mathrm{YP}\left(70 \mathrm{Ib} / \mathrm{ft}^{2}\right)$ at $30^{\circ} \mathrm{C}$, while $\mathrm{C} 1$ gave the lowest $\mathrm{YP}$ value $\left(22 \mathrm{Ib} / \mathrm{ft}^{2}\right)$ also at $30^{\circ} \mathrm{C}$. YP indicates the ability of the drilling mud to carry drilling cutting to the surface during drilling processes. However, the mud formulated with the various plant extracts gave YP values that are within the recommended range $\left(10-60 \mathrm{Ib} / \mathrm{ft}^{2}\right)(10-60 \mathrm{Ib} /$ $\mathrm{ft}^{2}$ ) (Li et al., 2016).

\subsubsection{Gel Strength}

The shear stress measured at low shear rate after the mud has set quiescently for a period of time (10 seconds, 10 minutes or even 30 minutes) is known as gel strength. Arrangement of clay platelets in a position of minimum energy to satisfy electrostatic surface charges bring about gel strength. Gel strength can occur as either progressive or flat.

Gel strength for C1, C2 and ALEM formulated muds at 10 seconds and 10 minutes were observed to be reduce as temperature increased. Decrease in gel strength is attributed to a decrease in the electrochemical interaction in the mud as temperature increases. Gel strength of mud formulated with the various $\mathrm{NaOH}$ plant extracts at different temperature varied from 4 to $14 \mathrm{Ib} / \mathrm{ft}^{2}$ for 10 seconds gel strength, and 5

TABLE 6: Dial REAding RESUlts of THE DIFFERENT FORMULATED NAOH PLANT EXTRACt DRILLING MUD

\begin{tabular}{ccccccccccccc}
\hline RPM & \multicolumn{3}{c}{ BLEM } & \multicolumn{3}{c}{ PLEM } & \multicolumn{3}{c}{ MLEM } & \multicolumn{3}{c}{ ALEM } \\
\hline & $30^{\circ} \mathrm{C}$ & $49^{\circ} \mathrm{C}$ & $60^{\circ} \mathrm{C}$ & $30^{\circ} \mathrm{C}$ & $49^{\circ} \mathrm{C}$ & $60^{\circ} \mathrm{C}$ & $30^{\circ} \mathrm{C}$ & $49^{\circ} \mathrm{C}$ & $60^{\circ} \mathrm{C}$ & $30^{\circ} \mathrm{C}$ & $49^{\circ} \mathrm{C}$ & $60^{\circ} \mathrm{C}$ \\
\hline 600 & 61 & 53 & 49 & 66 & 52 & 55 & 53 & 52 & 51 & 54 & 54 & 50 \\
300 & 43 & 40 & 38 & 47 & 42 & 45 & 41 & 40 & 39 & 41 & 43 & 41 \\
200 & 40 & 38 & 36 & 45 & 40 & 41 & 40 & 38 & 35 & 39 & 37 & 35 \\
100 & 37 & 35 & 33 & 41 & 38 & 39 & 37 & 33 & 32 & 35 & 34 & 34 \\
6 & 15 & 14 & 14 & 22 & 20 & 21 & 18 & 18 & 16 & 21 & 19 & 18 \\
3 & 10 & 8 & 5 & 15 & 14 & 14 & 15 & 16 & 14 & 20 & 18 & 17 \\
\hline
\end{tabular}




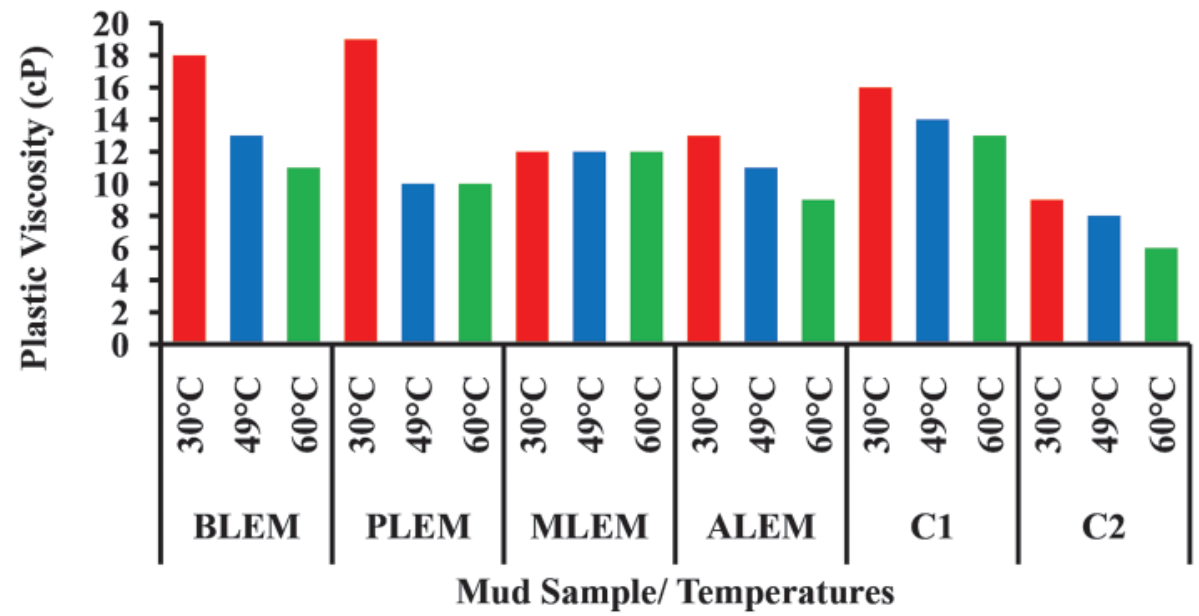

Fig.7 Effects of temperature on plastic viscosity

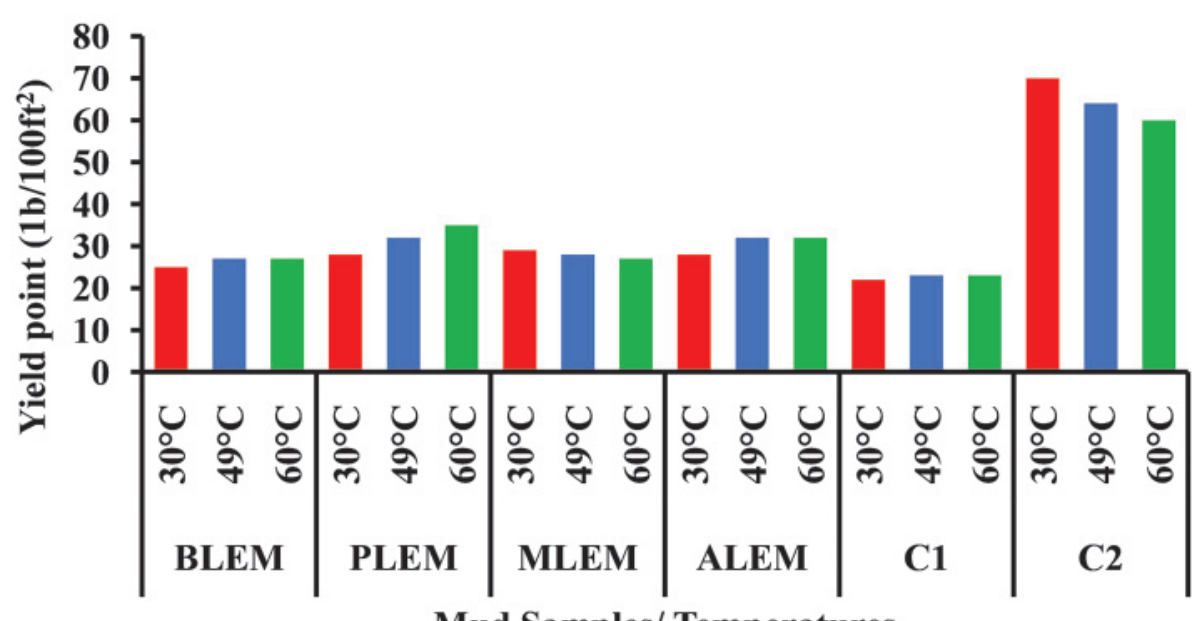

Mud Samples/ Temperatures

Fig.8 Effects of temperature on yield point

to $15 \mathrm{Ib} / \mathrm{ft}^{2}$ for 10 minutes gel strength. The gel strength (Fig.9) showed that flat gel strength occurred as there was no significant increase between gel strength at 10 seconds and 10 minutes at all the various test temperatures. Progressive gel strength makes the circulation of the drilling mud to be hard, which is why flat gel strength is always desirable. However, Biwott et al., (2019) observes both progressive and flat gel strength in their studies.

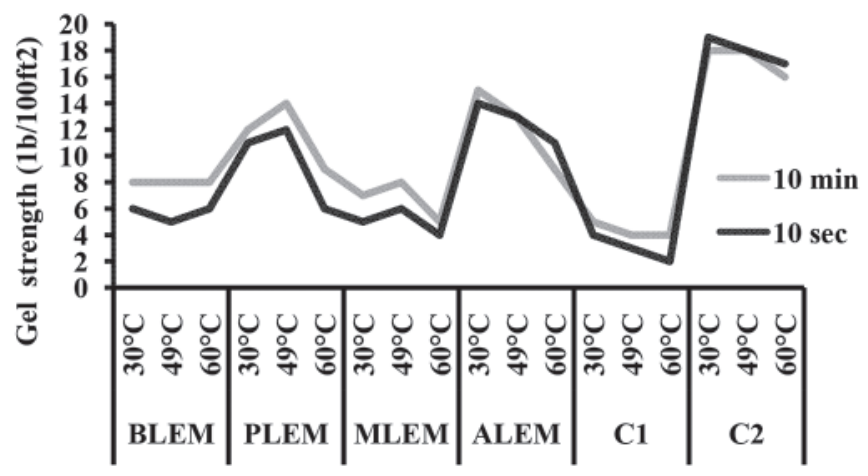

Fig.9 Effects of temperature on gel strength

\subsection{Filtration Loss}

Filtration loss was measured at 500 psi differential pressure and $121^{\circ} \mathrm{C}$ after 30 minutes. Bad fluid loss leads to very soft and thick mud cake across formation, which can lead to differential sticking. Also, thick filter cake leads to experiencing high torque and drag, while performing drilling and tripping (Lee and Shadravan, 2012).

Table 8 displays the results of the HPHT filtration loss test. The recommended specification by $\mathrm{Li}$ et al., (2016) is that the filtration volume be less than or equal to $10 \mathrm{ml}$ after 30 minutes of testing. All formulated drilling muds fulfill the ideal specification of having filtration loss of less than $10 \mathrm{ml}$, except $\mathrm{C} 2$ which has a filtration loss volume of $15 \mathrm{ml}$. The high filtration volume can be as a result of flocculation in the mud which promotes linking of the solid particles in the mud system in an edge-to-edge, as well as edge-to-face manner, which will result in the formation of an open network structure that favors fluid loss (Salih and Bilgesu, 2017).

3.6 EfFect of AgING 3.6.1 Rheology

Most polymers fail to maintain their rheological properties because of

Table 8: Filtration volume of the Different Formulated DRILLING FLUIDS

\begin{tabular}{lc}
\hline Mud type & Filtration loss $(\mathrm{ml})$ \\
\hline BLEM & 2 \\
PLEM & 8 \\
MLEM & 3 \\
ALEM & 5 \\
C1 & 2 \\
C2 & 15 \\
\hline
\end{tabular}

the degradation at high temperatures (Ahmed, 2017). The rheological properties (PV, YP and gel strength) were evaluated at $49^{\circ} \mathrm{C}$, which is said to be the standard temperature for evaluating these properties. From Table 9, there was decrease in PV (14-10 cP) and a decrease in YP (23$20 \mathrm{bb} / 100 \mathrm{ft}^{2}$ ) of the $\mathrm{C} 1$ mud after aging. The PV and YP of the $\mathrm{C} 2$ mud also followed the same trend as $\mathrm{C} 1$ mud after aging (from 8 to $3 \mathrm{cP}$ and 64 to $55 \mathrm{lb} / 100 \mathrm{ft}^{2}$ ) respectively. It was also observed that there was no much significant decrease in the PV values of the plant extract mud after aging of the mud 
at $65^{\circ} \mathrm{C}$. Decrease in PV after aging occurs as a result of the particles in the mud being less kinetically active, which results in fewer shears within the mud system. However, increase in PV values can lead to higher equivalent circulating density, surge and swab pressure increase, less rate of penetration as well as increase in differential sticking (Evelyn et al., 2018). Furthermore, YP values also reduce after aging of the mud. PLEM and ALEM gave YP value of $28 \mathrm{Ib} / 100 \mathrm{ft}^{2}$ which is observed to be the highest YP value in the various $\mathrm{NaOH}$ plant extract muds after aging.

Gel strength is an important parameter and shows the capacity of muds to suspend the solids in drilling process. In Table 9, it can be seen that there was decrease in gel strength at 10 seconds and 10 minutes for all the formulated mud. The decrease in gel strength could be attributed to the flocculation of bentonite clay (Hafiz et al., 2018). Higher gel strengths are not desirable, because separation of cuttings might be delayed while on the other hand, too low gel strengths will not be able to suspend the cuttings (Putri et al., 2015). The rheological properties (PV, YP and gel strength) obtained from the various muds after aging were within the recommended API range; thus the $\mathrm{NaOH}$ plant extracts was able to stabilize the rheological properties of the mud after aging.

TABle 9: Mud RHEOLOGY OF NAOH EXTRACTS MUdS AND CONTROL MUd AFTER AGING AT $65^{\circ} \mathrm{C}$

\begin{tabular}{lcccccc}
\hline \multicolumn{7}{c}{ Mud type } \\
\hline RPM & BLEM & PLEM & MLEM & ALEM & C1 & C2 \\
\hline 600 & 42 & 42 & 45 & 44 & 40 & 61 \\
300 & 32 & 35 & 35 & 36 & 30 & 58 \\
200 & 28 & 31 & 32 & 34 & 28 & 50 \\
100 & 25 & 28 & 28 & 30 & 22 & 45 \\
6 & 8 & 9 & 7 & 10 & 9 & 3 \\
3 & 8 & 9 & 6 & 9 & 8 & 2 \\
PV & 10 & 7 & 10 & 8 & 10 & 3 \\
Y P & 22 & 28 & 25 & 28 & 20 & 55 \\
GEL Strenght & & & & & & \\
10 min & 5 & 5 & 3 & 12 & 3 & 1 \\
10 sec & 4 & 2 & 2 & 2 & 2 & 0.3 \\
\hline
\end{tabular}

\subsection{Conclusion}

Research has shown that the performance of drilling mud during drilling operation is influenced by its properties such as mud viscosity, specific gravity, emulsion stability, $\mathrm{pH}$, and filtration loss, among others. In this study, $\mathrm{NaOH}$-extracts of bitter-leaf, pawpaw, moringa and almond leaves were used as emulsifying materials in drilling mud formulation. The formulated $\mathrm{NaOH}$ plant extract drilling mud properties were compared to drilling mud formulated with an industrial emulsifier. The formulated drilling mud had relatively good potential as when compared with drilling mud formulated with an industrial emulsifier:

Based on the results obtained from the study, the following conclusions can be drawn:
- The rheological properties of the various formulated drilling muds were influence by temperature. The rheology profiles show that with temperature increase, the plastic viscosity (PV) of BLEM, PLEM and ALEM decreases with the exception of MLEM which remained constant as temperature increases. Also, yield point of MLEM decreased as temperature increased, as well as the gel strength of the MLEM which decreased as temperature increased.

- The gel strength were observed to be a flat gel, since there was no much difference between gel at 10 seconds and 10 minutes for the various test temperatures. Flat gels are usually desirable, since it makes circulation of drilling mud easy when compared to a progressive gel.

- The filtration volume of the various formulated drilling mud where within the recommended range (d" $10 \mathrm{ml})$ with the exception of $\mathrm{C} 2$ that gave value of $15 \mathrm{ml}$. The resolved values show that differential sticking will not be experience when these muds are used for drilling.

- The rheological properties (PV, YP and gel strength) of the $\mathrm{NaOH}$-plant extracts mud after aging were observed to be thermally stable, as high temperature $\left(65^{\circ} \mathrm{C}\right)$ did not have much effect on the muds by degrading the additives use for its formulation. The surfactant present in the mud, improved the temperature resistance of the mud against thermal degradation, and also improves fluid loss.

\section{Conflict of interest}

The author(s) declared no potential conflicts of interest with respect to the research, authorship and/or publication of this article.

\section{Reference}

1. Agwu, O.E., Okon, A.N. and Udoh, F.D. (2015): A comparative study of diesel oil and soybean oil as oilbased drilling mud. Journal of Petroleum Engineering.

2. Ahmed, S. (2017): Effect of temperature on the rheological properties with shear stress limit of iron oxide nanoparticle modified bentonite drilling muds. Egyptian Journal of Petroleum; 26:791-802.

3. Akintola, S., Oriji, A. B and Momodu, M (2014): "Analysis of filtration properties of locally sourced base oil for the formulation of oil based drilling fluids," ScientiaAfricana, vol.13, no.1, pp.171-177.

4. Amanullah, M., Ramasamy, J., Al-Arfaj, M. K., Aramco, S.(2016): Application of an indigenous eco-friendly raw material as fluid loss additive. Journal of Petroleum Science and Engineering.139:191-197.

5. Avci, E. and Mert, B.A. (2019): The Rheology and Performance of Geothermal Spring Water-Based Drilling Fluids. Geofluids.

6. Biwott, Tecla., Akaranta, Onyewuchi., Kiprop, K. Ambrose and Boniface, Oriji. (2019): Improving the rheological 
properties of water based mud with Moringa olerifera leaves. Chemical science international Journal. 28(4): 1-9.

7. Dong, X., Wang, L., Yang, X., Lin, Y and Xue, Y (2015): Effect of ester based lubricant SMJH-1 on the lubricity properties of water based drilling fluid. Journal of Petroleum Science and Engineering. 135:161167

8. Eka, E.C.L., Dadang, D., Manuwoto, S.M. and Syahbirin, G.S. (2017): Formulation of Mixed Extracts of Tephrosia vogelii and Piper aduncum.

9. Evelyn, E., Adewale, D and Sunny, I. (2018): Optimizing aqueous drilling mud system viscosity with green additives. Journal of Petroleum exploration and production technology; 9:315-318

10. Fadare, O., Durosinmi, O., Fadare, R., Izevbekhai, O., Awonyemi, I.O. and Obafemi, C.A. (2015): ATR-FTIR and HPLC spectroscopic studies and evaluation of mineral content of Carica papaya leaves and flowers.

11. Fasya, A.G., Baderos, A., Madjid, A.D.R., Amalia, S. and Megawati, D.S. (2019): Isolation, identification and bioactivity of steroids compounds from red algae Eucheuma cottonii petroleum ether fraction. Paper presented at the AIP Conference Proceedings.

12. Friedheim, J. E. (1998): “Area-specific analysis reflects impact of new generation fluid systems on deepwater exploration," in Proceedings of the IADC/SPE Asia Pacific Drilling Technology Conference, IADC/SPE47842, Society of Petroleum Engineers, Jakarta, Indonesia, September.

13. Hafiz, M., Muhammad, S and Mamdouh, A.(2018): High molecular weight copolymers as rheology modifier and fluid loss additive for water-based drilling fluids. Journal of Molecular Liquids; 252:133-143.

14. Huo, W.-L., Qi, F., Zhang, X.-Y., Ma, N., Gan, K., Qu, Y.-N., $\mathrm{Xu}$, J. and Yang, J.-L. (2016): Ultralight alumina ceramic foams with single-grain wall using sodium dodecyl sulfate as long-chain surfactant. Journal of the European Ceramic Society, 36(16), 4163-4170.

15. Hughes, B. (2006): Drilling Fluids Reference Manual.

16. Ihenacho, P., Burby, M., Nasr, G, and Enyi, G. (2016): 50/50 oil-water ratio invert emulsion drilling mud using vegetable oil as continuous phase. International Journal of Chemical, Molecular, Nuclear, Materials and Metallurgical Engineering.10(3):239-242

17. Jain, A., Joshi, A., Joshi, J., Tatawat, M., Saeed, S., Telang, S., Choubey, Y. and Puri, P. (2019): Comparative study of phytochemical screening and antibacterial activity of four medicinal plants. Journal of Medicinal Plants, 7(4), 81-89.

18. Jimoh, K., Muritala, K and Musliu, O (2018): Oil field chemicals from macromolecular renewable resources in Nigeria: An integration of hydrocarbon recovery with bioresource utilization. NSCHE Journal. 33(1):8686.

19. Khodja, M., Khodja-Saber, M., Canselier, J. P., Cohaut, N. and Bergaya, F. (2010): 'Drilling fluid technology: performances and environmental considerations', Product and Services, From R\&D to final solutions, pp. 227-232.

20. Lee, J., \& Shadravan, A. (2012): Rheological Properties of Invert Emulsion Drilling Fluid Under Extreme HPHT Conditions. Paper IADC/SPE 151413, presented at IADC/ SPE Drilling Conference and Exhibition, 6-8 March 2012, San Diego, California.

21. Li, W., Zhao, X., Ji, Y., Peng, H., Chen, B., Liu, L and Han, X. (2016): Investigation of biodiesel based drilling fluid, Part1: Biodiesel evaluation, invert-emulsion properties, and development of a novel emulsifier package, society of petroleum engineers, SPEJ. https://doi.org/10.2118/ 180918-PA.

22. Li, Z., Vandenbossche, J., Iannacchione, A., Brigham, J. and Kutchko, B. (2016): Theory-based review of limitations with static gel strength in cement/matrix characterization. SPE Drilling \& Completion, 31(02), 145-158.

23. Mohammed, A. (2007): "Environmentally friendly mud additives for superior drilling-fluid design to meet the current and future technical and environmental challenges", The Oil and Gas Review, Issue 11.

24. Mohideen, A. A. M., Saheed, M. S. M and Mohamed, N.M. (2019): Multiwall carbon nanotubes and graphene oxide as nano-additives in water-based drilling fluid for enhanced fluid-loss-control \& gel strength. Paper presented at the AIP Conference Proceedings.

25. Olatunde, A. O., Usman, M. A., Oladafenan, O. A., Adeosan, T. A, and Ufot, O. E. (2011): "Improvement of rheological properties of drilling fluid using locally based material", Petroleum and Coal, vol.54, no.1, pp 65-75.

26. Putri, Y., Sonny, I and Dina, K. (2015): Evaluation of Nonionic and anionic surfactants as additives for water-based mud. American Journal of Chemistry; 5:52-55.

27. Rio, E., Drenckhan, W., Salonen, A. and Langevin, D. (2014): Unusually stable liquid foams. Advances in colloid and interface science, 205, 74-86.

28. Salih, A. H and Bilgesu, H. (2017): Investigation of Rheological and Filtration Properties of Water-Based Drilling Fluids Using Various Anionic Nanoparticles, Society of Petroleum Engineers, SPEW estern Regional Meeting, 23-27 April, Bakersfield, California, https:// doi.org/10.2118/185638-MS.

29. Talukdar, P., Kalita, S., Pandey, A., Dutta, U, and Singh, R. (2018): Use of tannate derived from tea waste as drilling fluid additive. International Journal of Applied Engineering Research. 13(16):12463-12468.

30. Tchameni, A., Zhao, L., Frimpong, I and Nagre, R. (2018): Investigating the effect of high thermal-saline conditions on the rheological properties of waste vegetable oil biodiesel based emulsion mud. Journal of petroleum exploration and production technology. 8(1):155-164

31. Yunita, P., Irawan, S. and Kania, D. (2015): Evaluation of non-ionic and anionic surfactants as additives for waterbased mud. American Journal of Chemistry, 5, 52-55 